\title{
Stigmatizing attitudes in relatives of people with schizophrenia: a study using the Attribution Questionnaire AQ-27
}

\author{
Atitudes estigmatizantes em familiares de pessoas com esquizofrenia: \\ um estudo utilizando o Attribution Questionnaire AQ-27
}

\author{
Sara de Sousa, ${ }^{1}$ António Marques, ${ }^{2}$ Rosário Curral, ${ }^{3}$ Cristina Queirós ${ }^{4}$
}

\begin{abstract}
Background: Family members of people with mental disorders can contribute to stigmatization. Because of the lack of adequate information and resources, and the fatigue resulting from daily care, the family can reinforce social exclusion of the mentally ill and disbelieve recovery. Furthermore, family members may also suffer from self-stigma, experiencing a decrease in their own self-esteem and self-worth.

Objective: To evaluate the presence of stigmatizing attitudes towards patients diagnosed with schizophrenia in a group of relatives of patients with this disorder.

Methods: In this exploratory study, we surveyed 40 family members of patients with schizophrenia seen at the Community Psychiatry Unit of the Psychiatry Department at Centro Hospitalar de São João (CHSJ), in Porto, Portugal, using a preliminary version of the Attribution Questionnaire AQ-27 in Portuguese.

Results: The questionnaire dimensions with the highest mean scores were help, pity, and coercion, followed by segregation, anger, avoidance, dangerousness, responsibility, and fear. These results suggest that relatives do not see people with schizophrenia as responsible for their illness and that they show concern and willingness to help. They avoid but do not fear people with schizophrenia and neither consider them dangerous.

Conclusion: The participants expressed positive, little stigmatizing attitudes towards people with schizophrenia, probably as a result of their familiarity with severe mental disorder, an adequate attribution process, and low levels of perceived dangerousness. However, the high scores of coercion, pity, and segregation may reflect concealed stigmas that may influence the self-determination of the mentally ill, suggesting the need for psychoeducational interventions aimed at family members.
\end{abstract}

Keywords: Social stigma, family relations, schizophrenia.

\section{Resumo}

Introdução: Na doença mental, a família pode ser um agente do processo de estigmatização. Devido à falta de informação adequada e de recursos e ao cansaço decorrente do processo de cuidar, ela pode contribuir para a exclusão social do familiar doente e desinvestir na sua recuperação. Além disso, pode também ser detentora de autoestigma, observando-se uma diminuição da autoestima e da autovalorização da família.

Objetivo: Avaliar a presença de atitudes estigmatizantes em um grupo de familiares de pacientes com esquizofrenia, relativamente às pessoas com esse diagnóstico.

Método: Neste estudo exploratório, foram inquiridos 40 familiares de pacientes com esquizofrenia tratados na Unidade de Psiquiatria Comunitária do Serviço de Psiquiatria do Centro Hospitalar de São João (CHSJ), em Porto, Portugal, utilizando a versão portuguesa preliminar do Attribution Questionnaire AQ-27.

Resultados: As dimensões do questionário que apresentaram médias mais elevadas foram ajuda, pena e coação, seguidas de segregação, irritação, evitamento, perigo, responsabilidade e, por último, medo. Esses resultados sugerem que os familiares não atribuem às pessoas com esquizofrenia a responsabilidade de estarem doentes e que mostram preocupação e disponibilidade para ajudar. Eles evitam as pessoas com esquizofrenia mas não sentem medo delas nem as consideram perigosas.

Conclusão: Os participantes manifestam atitudes positivas e pouco estigmatizantes para com as pessoas com esquizofrenia, decorrentes da sua familiaridade com a doença mental grave, de um processo de atribuição adequado e da baixa percepção de perigosidade. Contudo, os valores de coação, pena e segregação podem traduzir algum estigma encoberto que pode influenciar a autodeterminação da pessoa com experiência de doença mental grave, sugerindo-se intervenções no âmbito da psicoeducação familiar.

Descritores: Estigma social, relação familiar, esquizofrenia.

\footnotetext{
${ }_{1}^{1}$ PhD in Psychology, Psychiatry Department, Centro Hospitalar de São João (CHSJ), Porto, Portugal. ${ }^{2}$ PhD in Psychology, Escola Superior de Tecnologia da Saúde - Instituto Politécnico do Porto (ESTS-IPP), Porto, Portugal. ${ }^{3}$ MSc in Psychiatry and Mental Health, Psychiatry Department, Centro Hospitalar de São João (CHSJ), Porto, Portugal. ${ }^{4}$ PhD in Psychology, Faculdade de Psicologia e Ciências da Educação da Universidade do Porto (FPCEUP), Porto, Portugal.

The present study was carried out at the Psychosocial Rehabilitation Laboratory of Faculdade de Psicologia e Ciências da Educação da Universidade do Porto (FPCEUP), Porto, Portugal, and Escola Superior de Tecnologia da Saúde - Instituto Politécnico do Porto (ESTS-IPP), Porto, Portugal.
}

Submitted Dec 6 2011, accepted for publication Mar 7 2012. No conflicts of interest declared concerning the publication of this article.

Suggested citation: Sousa S, Marques A, Curral R, Queirós C. Stigmatizing attitudes in relatives of people with schizophrenia: a study using the Attribution Questionnaire AQ-27. Trends Psychiatry Psychother. 2012;34(4):186-97. 


\section{Introduction}

In general, all psychiatric disorders elicit feelings of strangeness and discomfort, which may create stigma and lead to the social exclusion of the mentally ill and of the people relating with them. In the past decade, an increase has been observed in research into stigmatic attitudes toward mental disorders, which has allowed us to improve our knowledge on the topic. Theories and conceptual models have been proposed by different authors to explain the phenomenon, e.g.: Corrigan et al. ${ }^{1}$ and Watson et al., ${ }^{2}$ both from the United States and both from the field of social psychology; Link \& Phelan, ${ }^{3}$ also from the U.S., writing from a sociological perspective; Angermeyer et al., ${ }^{4}$ from Germany, and Sartorius et al., ${ }^{5}$ from Switzerland, both closely related with the World Psychiatric Association; and Thornicroft et al., from England, affiliated with the Institute of Psychiatry at King's College London. ${ }^{6}$

For the scope of the present study, the model developed by Corrigan et al. was considered the most useful one. In order to achieve a better understanding of the attitudes and phenomena related with stigma towards people with mental disorders, those authors developed classification systems and models to explain different constructs. Corrigan \& Watson ${ }^{7}$ proposed two categories of stigma, namely public or social stigma and self-stigma. Social stigma is defined as a phenomenon in which social groups rely on certain stereotypes and act against stigmatized groups - in our case, people with mental disorders. According to those authors, our culture is filled with mental illness-related stigmatizing images, which lead people experiencing the condition to agree and adopt the socially accepted stereotypes. This phenomenon produces the so-called self-stigma, characterized by a decrease in self-esteem and self-confidence, which in turn provoke social isolation, difficulties seeking help, poor adherence to treatment, and attitudes such as disbelief in recovery and hopelessness. ${ }^{7,8}$

Corrigan ${ }^{9}$ suggests the use of the cognitive-social model to explain the relationship between discriminative stimuli (cues) and the consequent behaviors (discrimination) when identifying the mental processes that permeate these constructs (stereotypes and prejudice). In this scenario, stigma is defined as comprising three fundamental elements: stereotype, prejudice, and discrimination. Subsequently, Corrigan et al. ${ }^{10}$ developed a new model to explain the relationship between causal attributions (controllability and responsibility), familiarity with mental illness, perceived dangerousness, emotional responses (e.g., pity, anger, fear), and helping or rejecting responses. This model was named Attribution Model of Public Discrimination towards Persons with Mental Illness, based on the Attribution Model of Helping Behavior proposed by Weiner ${ }^{11}$; the latter, in turn, designed his model based on the work of Heider, ${ }^{12}$ the first author to propose an attribution theory in psychology.

From the point of view of social psychology and according to Heider, ${ }^{12}$ attribution is the way how individuals explain the causes of phenomena, attitudes, the behaviors of others and their own behaviors. The psychological attribution theory became a major paradigm in social psychology research, as it suggests that human beings are always trying to find out the reason why someone has certain behaviors, i.e., trying to attribute one or more causes to such behaviors, continuously and spontaneously producing causal inferences for a given event or behavior. Such inferences may become beliefs or expectations, and may lead to the process of predicting the very course or evolution of the event, ultimately having a strong influence on the subjects' attitudes and behaviors. For Heider, ${ }^{12}$ there are two subtypes of attributions: internal attributions, when behaviors are perceived as being caused by factors such as personality, character, and disposition; and external attributions, when behaviors are thought to be the consequence of a factor related with the situation in which the subject is involved.

Indeed, stigma may hinder both treatment-seeking and recovery of the mentally ill. The World Health Organization has identified stigma as the main cause of discrimination and social exclusion, as it affects the person's self-esteem, limits social functioning, hinders the successful acquisition of a home and a job, and contributes to family dysfunction. ${ }^{13,14}$ Such discriminative behaviors become even stronger when individuals are faced with a diagnosis of schizophrenia, due to its typical symptoms, disruptive behaviors, and the dangerousness commonly associated with the disorder. ${ }^{15,16}$

The way how society sees and fights stigma is historically influenced by the way how madness and mental illness have been conceptualized over time. Such conception, also observed in the nuclear family, is frequently based on myths of incapacity, dangerousness, and the irreversible nature of severe mental illness, and still today poses more or less conscious obstacles to the functional competency and recovery possibilities of the mentally ill. ${ }^{17}$ Notwithstanding, people with a mental illness are not the only ones affected by stigma and its consequences. Prejudice and discrimination also affect family members, caregivers, and other people with close relationships with the patient. This phenomenon was referred to as associative stigma by Goffman in $1963 .{ }^{18,19}$ It can create self-stigma among family members themselves, with a decrease in self-esteem and self-worth. Struening et al. ${ }^{20}$ observed that $70 \%$ of family members believed that people with severe mental 
illness were depreciated by the general population and that this stigmatizing attitude also affected the family. In the past decade, several studies have identified negative impacts of stigma on the lives of relatives of people with schizophrenia, commonly affecting sleep, interpersonal relationships, subjective well-being, and quality of life. ${ }^{21}$

From a different standpoint, the family can itself operate as a stigmatizing agent, usually due to the lack of adequate information and resources, and the fatigue resulting from daily care, the result being a reinforcement of social exclusion behaviors and the relatives' disbelief in recovery. ${ }^{22}$ Indeed, mental disorders strongly affect family dynamics: on the one hand, the family has to organize routines so as to ensure that the tasks and roles of the patient will be fulfilled; on the other hand, it has to provide the necessary assistance to the patient. This scenario generates tensions, often experienced with anxiety and fear of the future, and leads to the adoption of attitudes that may include both rejection and protectionism, indifference and conflict. ${ }^{23}$ The illness also has impacts on the financial overload and physical and emotional distress of family members, as a result of either trying to hide the problem, or avoiding professional and community discrimination. ${ }^{22}$

In a recent review, Larson \& Corrigan ${ }^{24}$ concluded that mental health services should offer interventions directed at family members, teaching them strategies to deal with stigma. Similarly, Almeida et al. ${ }^{25}$ in a qualitative study involving 15 informal caregivers of patients with schizophrenia, concluded that specific interventions are needed to "take care of the caregiver," as these people tend to complain of negative and permanent impacts associated with caregiving. The main factors identified as reducing the burden of caregivers are social and family support, the availability of places/opportunities for caregivers to relieve tensions, physical distance from the patient, and appreciation of the pharmacological treatment.

Providing information on mental disorders also has to be a priority, and should include factors related with stress and its consequences throughout life, the importance of social support, with the family advocacy in obtaining effective treatments, and the vital need for relatives to preserve and watch over their own wellbeing, in the same way they do with their mentally ill family member. ${ }^{17,26}$ Over the past decades, a significant increase has been observed in the number of advocacy and self-help groups, a phenomenon that has changed the status of people with mental disorders and particularly of their families, who changed from passive, culpable, victimized family members to advocates of their own and their family's well-being, as well as of social changes.

For Hinshaw, ${ }^{17}$ family participation in these groups has several benefits: it allows families to publicly acknowledge their proximity to the disease, opposing the silence and shame usually shown by relatives; it offers social support by sharing resources and coping strategies among group participants, reducing the isolation so commonly associated with mental illness; through its educational component, it raises awareness and promotes mental illness-related knowledge; and it contributes to social change, as family members get collectively involved in fighting prejudice and discrimination in the community.

According to the 2009 guidelines of the National Collaborating Centre for Mental Health (NCCMH), family interventions are considered one of the most effective therapies in schizophrenia, with evidence suggesting that family-oriented psychoeducational programs are useful in the patient's recovery process and reduce relapse rates, particularly in this severe mental disorder. Notwithstanding, Cabral \& Chaves $^{27}$ alert to the fact that this type of intervention should provide responses to the specific needs of the target population; therefore, the investigation of such needs cannot be neglected.

In spite of the negative effects of caregiving for the family, some positive aspects can also be observed, including feelings of achievement and personal growth. Mental health professionals should help relatives make decisions so as to achieve a satisfactory performance and help them express their positive feelings associated with the mentally ill family member. ${ }^{28}$ For McFarlane, given the specificities of severe mental illness and the burden of family caregiving, teamwork between family members and mental health professionals should be an option, but rather a requirement. We may therefore state that taking care of the well-being of patients with a severe mental disorder also includes taking care of their relatives. ${ }^{22}$

In order to pay attention to and care for the real needs of families, it is important to know in detail some of the attitudes that may promote or inhibit stigma. Because no studies have been conducted in this field with family members of patients diagnosed with schizophrenia in Portugal, the aim of the present study was to evaluate the presence of stigmatizing attitudes towards patients diagnosed with schizophrenia in a group of relatives of patients with this disorder seen at the psychiatric service of a major general hospital in the country.

\section{Method}

\section{Instruments}

The Attribution Questionnaire AQ-2729,30 (a preliminary version in Portuguese approved for use by the author of the original instrument) and a short questionnaire covering sociodemographic data were used. The AQ-27 
was designed to assess nine stereotypes about people with mental illness: responsibility (people with mental illness can control their symptoms and are responsible for having the illness), pity (people with mental illness are overtaken by their own disorder and therefore deserve concern and pity), anger (people with mental illness are blamed for having the illness and provoke wrath and rage), dangerousness (people with mental illness are not safe), fear (people with mental illness are dangerous), help (people with mental illness need assistance), coercion (people with mental illness have to participate in treatment management), segregation (people with mental illness are sent to institutions located far from the community), and avoidance (patients with mental illness do not live in society). Corrigan et al. have associated some of these constructs with discriminative attitudes (responsibility, dangerousness, fear, anger, coercion, segregation, and avoidance) and others with attitudes of closeness and assistance (help and pity). ${ }^{10}$

The AQ-27 comprises a vignette about a patient with schizophrenia, followed by 27 statements that have to be scored using a 9-point Likert scale, where 1 means "no or nothing" and 9 means "very much or completely." Results are calculated considering the mean scores (not their sum) obtained for the items comprising each construct. Questions in the avoidance dimension are reverse scored. The questionnaire contains several alternative vignettes, corresponding to variations in the characteristics of the mental illness assessed, especially regarding severity. The following vignette was used in the present study: "Harry is a 30 year-old single man with schizophrenia. Sometimes he hears voices and becomes upset. He lives alone in an apartment and works as a clerk at a large law firm. He has been hospitalized six times because of his illness."

Because we used a preliminary version of the AQ27 in Portuguese, the psychometric properties of the instrument were assessed, yielding an alpha of 0.88 , close to that reported in other studies conducted in Portugal, namely, $0.76^{31}$ and $0.83 .{ }^{32}$

\section{Procedures}

Between May and June 2011, the preliminary Portuguese version of the AQ-27 was administered to all participants accompanying family members with schizophrenia at the Community Psychiatry Unit of the Psychiatry Department at Centro Hospitalar de São João (CHSJ), in Porto, Portugal, while the patients received an extended-release injection. We adopted an accidental sampling technique, i.e., people waiting at the reception, and instrument application lasted 5 minutes on average. All participants signed an informed consent form before entering the study.
The research protocol was approved by the Research Ethics Committee of CHSJ. Results were analyzed using the PASW Statistics software version 18. Descriptive statistics and comparative analyses were conducted using one-way analysis of variance (ANOVA) and Pearson's correlation coefficient.

\section{Results}

The sample comprised 40 relatives of patients with schizophrenia seen at the Community Psychiatry Unit of the Psychiatry Department at CHSJ, Porto, Portugal. Participants' age ranged from 32 to 75 years (mean = 54.9 , standard deviation [SD] $=13.03)$; most were female $(70 \%)$, married $(77 \%)$, retired or not working $(55 \%)$, and had low levels of education ( $43 \%$ with elementary school only). With regard to type of relationship, $43 \%$ were parents, $33 \%$ were siblings or siblings-in-law, and $15 \%$ were spouses; most of the family members lived with the mentally ill (70\%). Illness duration ranged between 3 and 37 years (mean $=19.26$, SD $=9.8$ ), evidencing a long disease course. In order to preserve patients' anonymity, we did not collect more specific data about the mentally ill, e.g., their age and sex.

Mean results obtained for each item/statement comprising the AQ-27 are presented in Table 1. Coercion was the construct with the highest scores: the item "If I were in charge of Harry's treatment, I would require him to take his medication" had most responses close to the maximum score and had 5 as a minimum score. Items related to help and pity constructs also scored high, especially "How likely is it that you would help Harry?" and "How much concern would you feel for Harry?" The avoidance construct showed high mean values for "If I were an employer, I would interview Harry for a job," "I would share a car pool with Harry every day," and "If I were a landlord, I probably would rent an apartment to Harry." The item with the lowest score was in the responsibility construct, namely, "I would think that it was Harry's own fault that he is in the present condition," with a maximum score of 6 .

The stereotypes/dimensions of the AQ-27 with the highest overall mean scores were help, pity, and coercion, whereas responsibility, fear, dangerousness, and avoidance presented lower scores (Table 2).

Comparative analyses revealed very few statistically significant differences. Therefore, we chose to disclose here only the comparisons yielding significant results and list all other non-significant results in Appendix 1. Table 3 shows the significant results obtained for type of relationship in the coercion dimension, with spouses showing lower scores when compared with other relatives, e.g., grandparents and nieces/nephews ( $p=0.033)$. 
Table 1 - Means obtained in AQ-27 items

\begin{tabular}{|c|c|c|c|c|c|}
\hline Items & Dimension & Min & Max & Mean & SD \\
\hline I would feel aggravated by Harry. & Anger & 1 & 9 & 4.20 & 3.031 \\
\hline How angry would you feel at Harry? & & 1 & 9 & 2.60 & 2.394 \\
\hline How irritated would you feel by Harry? & & 1 & 9 & 2.85 & 2.119 \\
\hline I would feel unsafe around Harry. & Dangerousness & 1 & 9 & 2.83 & 2.374 \\
\hline How dangerous would you feel Harry is? & & 1 & 9 & 3.85 & 2.167 \\
\hline I would feel threatened by Harry. & & 1 & 9 & 2.65 & 2.315 \\
\hline Harry would terrify me. & Fear & 1 & 9 & 2.68 & 2.347 \\
\hline How scared of Harry would you feel? & & 1 & 9 & 2.68 & 2.246 \\
\hline How frightened of Harry would you feel? & & 1 & 9 & 2.68 & 2.303 \\
\hline $\begin{array}{l}\text { If I were in charge of Harry's treatment, I would require him to take his medication. } \\
\text { How much do you agree that Harry should be forced into treatment with his }\end{array}$ & Coercion & 5 & 9 & 8.75 & 0.927 \\
\hline doctor even if he does not want to? & & 1 & 9 & 8.45 & 1.782 \\
\hline If I were in charge of Harry's treatment, I would force him to live in a group home. & & 1 & 9 & 3.40 & 2.781 \\
\hline I think Harry poses a risk to his neighbors unless he is hospitalized. & Segregation & 1 & 9 & 5.90 & 2.799 \\
\hline $\begin{array}{l}\text { I think it would be best for Harry's community of he were put away in a psychiatric } \\
\text { hospital. }\end{array}$ & & 1 & 9 & 3.92 & 3.115 \\
\hline $\begin{array}{l}\text { How much do you think an asylum, where Harry can be kept away from his } \\
\text { neighbors, is the best place for him? }\end{array}$ & & 1 & 9 & 2.38 & 2.404 \\
\hline If I were an employer, I would interview Harry for a job. & Avoidance & 1 & 9 & 6.73 & 2.542 \\
\hline I would share a car pool with Harry every day. & & 1 & 9 & 6.88 & 2.893 \\
\hline If I were a landlord, I probably would rent an apartment to Harry. & & 1 & 9 & 6.78 & 2.259 \\
\hline I would be willing to talk to Harry about his problems. & Help & 1 & 9 & 7.65 & 2.143 \\
\hline How likely is it that you would help Harry? & & 1 & 9 & 7.90 & 1.598 \\
\hline How certain would you feel that you would help Harry? & & 1 & 9 & 6.40 & 2.205 \\
\hline I would feel pity for Harry. & Pity & 1 & 9 & 6.48 & 2.926 \\
\hline How much sympathy would you feel for Harry? & & 1 & 9 & 6.33 & 2.921 \\
\hline How much concern would you feel for Harry? & & 1 & 9 & 7.88 & 1.911 \\
\hline I would think that it was Harry's own fault that he is in the present condition. & Responsibility & 1 & 6 & 1.30 & 0.966 \\
\hline How controllable, do you think, is the cause of Harry's present condition? & & 1 & 9 & 4.38 & 2.227 \\
\hline How responsible, do you think, is Harry for his present condition? & & 1 & 9 & 3.13 & 2.127 \\
\hline
\end{tabular}

Max = maximum; Min = minimum; SD = standard deviation.

Table 2 - Means obtained for each stereotype/dimension in the AQ-27

\begin{tabular}{lcccc}
\hline Items & Minimum (1) & Maximum (9) & Mean & SD \\
\hline Responsibility & 1.00 & 5.00 & 2.93 & 1.128 \\
Pity & 3.00 & 9.00 & 6.89 & 1.769 \\
Anger & 1.00 & 7.67 & 3.22 & 1.876 \\
Dangerousness & 1.00 & 9.00 & 3.11 & 1.924 \\
Fear & 1.00 & 9.00 & 2.68 & 2.242 \\
Help & 1.00 & 9.00 & 7.32 & 1.551 \\
Coercion & 3.67 & 9.00 & 6.87 & 1.233 \\
Segregation & 1.33 & 9.00 & 4.03 & 2.165 \\
Avoidance & 1.00 & 9.00 & 3.21 & 2.229 \\
\hline
\end{tabular}

$\mathrm{SD}=$ standard deviation.
Table 3 - Comparison of means according to type of relationship

\begin{tabular}{lccccc}
\hline \multicolumn{1}{c}{} & $\mathbf{n}$ & Mean & SD & ANOVA (F) & $\mathbf{p}$ \\
\hline Responsibility & - & - & - & 0.768 & 0.519 \\
Pity & - & - & - & 1.284 & 0.295 \\
Anger & - & - & - & 1.244 & 0.308 \\
Dangerousness & - & - & - & 0.935 & 0.434 \\
Fear & - & - & - & 0.996 & 0.406 \\
Help & - & - & - & 1.172 & 0.334 \\
Segregation & - & - & - & 2.191 & 0.106 \\
Avoidance & - & - & - & 0.080 & 0.971 \\
Coercion & & & & & \\
$\quad$ Parents & 17 & 6.65 & 1.417 & & \\
$\quad$ Spouse & 6 & 6.17 & 0.782 & & \\
$\quad$ Siblings/Siblings-in-law & 13 & 7.03 & 0.907 & & \\
$\quad$ Other & 4 & 8.33 & 0.720 & & \\
$\quad$ Total & 40 & 6.87 & 1.233 & 3.269 & $0.032 *$ \\
\hline
\end{tabular}

$\mathrm{SD}=$ standard deviation.

$* \mathrm{p}<0.050$. 
Table 4 - Comparison of means according to education level

\begin{tabular}{lccccc}
\hline & $\mathbf{n}$ & Mean & SD & ANOVA (F) & p \\
\hline Responsibility & - & - & - & & \\
Coercion & - & - & - & & \\
Anger & - & - & - & & \\
Dangerousness & - & - & - & & \\
Fear & - & - & - & & \\
Help & - & - & - & & \\
Segregation & - & - & - & & \\
Avoidance & - & - & - & & \\
Pity & & & & & \\
$\quad$ Up to 4th grade & 17 & 23.35 & 3.757 & & \\
$\quad$ Up to 9th grade & 11 & 20.73 & 5.387 & & \\
$\quad$ 12th or beyond & 12 & 16.83 & 5.078 & & \\
$\quad$ Total & 40 & 20.68 & 5.308 & 6.918 & $0.003^{*}$ \\
\hline
\end{tabular}

$\mathrm{SD}=$ standard deviation

$* p<0.010$.
Table 5 - Comparison of means according to illness duration

\begin{tabular}{lccccc}
\hline & $\mathbf{n}$ & Mean & SD & ANOVA (F) & $\mathbf{p}$ \\
\hline Responsibility & - & - & - & 0.480 & \\
Pity & - & - & - & 0.525 & \\
Anger & - & - & - & 0.161 & \\
Dangerousness & - & - & - & 0.095 & \\
Fear & - & - & - & 0.659 & \\
Help & - & - & - & 0.767 & \\
Segregation & - & - & - & 0.200 & \\
Avoidance & - & - & - & 1.606 & \\
Coercion & & & & 3.441 & \\
$\quad$ 3 to 9 years & 6 & 23.00 & 2.828 & & \\
$\quad$ 15 to 21 years & 11 & 20.64 & 3.854 & & \\
$\quad$ 24 to 37 years & 10 & 17.90 & 3.143 & & \\
$\quad$ Does not know & 13 & 21.54 & 3.382 & & \\
$\quad$ Total & 40 & 20.60 & 3.699 & 3.441 & $0.027^{*}$ \\
\hline
\end{tabular}

$\mathrm{SD}=$ standard deviation.

$* \mathrm{p}<0.050$.

Table 6 - Correlation between different AQ-27 dimensions and between each dimension and participant's age (Pearson's coefficient)

\begin{tabular}{|c|c|c|c|c|c|c|c|c|c|}
\hline & Age & Responsibility & Pity & Anger & Dangerousness & Fear & Help & Coercion & Segregation \\
\hline Responsibility & -0.209 & & & & & & & & \\
\hline Pity & 0.312 & $-0.354 *$ & & & & & & & \\
\hline Anger & 0.004 & 0.279 & 0.134 & & & & & & \\
\hline Dangerousness & -0.170 & $0.472^{+}$ & -0.073 & $0.499^{+}$ & & & & & \\
\hline Fear & -0.0117 & $0.458^{+}$ & 0.100 & $0.616^{+}$ & $0.749^{+}$ & & & & \\
\hline Help & 0.178 & -0.284 & 0.128 & -0.128 & $-0.518^{+}$ & $-0.413^{+}$ & & & \\
\hline Coercion & -0.201 & 0.286 & -0.086 & 0.295 & 0.216 & 0.261 & -0.043 & & \\
\hline Segregation & 0.187 & 0.006 & $0.353 *$ & 0.280 & $0.431^{+}$ & $0.561^{+}$ & -0.282 & 0.101 & \\
\hline Avoidance & -0.0239 & $0.452 \dagger$ & 0.038 & $0.331 *$ & $0.633^{+}$ & $0.736^{+}$ & $-0.590^{+}$ & $0.388 *$ & $0.494^{+}$ \\
\hline
\end{tabular}

$* \mathrm{p}<0.05$.

$+p<0.01$.

Table 4 shows the significant results obtained for education level in the pity dimension, which showed higher scores associated with lower education levels (up to 4th grade) when compared with participants with higher education levels ( 12 th grade or beyond) $(p=0.002)$.

Illness duration showed significant differences in the coercion dimension: a shorter duration was associated with higher coercion scores (Table 5$)(p=0.037$ ).

No significant correlations were found between the different dimensions of the AQ-27 and participants' age. Significant positive and negative correlations observed among the dimensions are shown in Table 6.

\section{Discussion}

The relatives of patients with severe mental illness interviewed in the present study showed a tendency towards attitudes of closeness, protection, and assistance (help and pity dimensions), with few discriminative attitudes (e.g., coercion dimension). These results are in line with the study of Wong et al., ${ }^{21}$ who observed low levels of stigma among family members of patients with severe mental illness. When comparing the attitudes of our participants with those of other studies conducted with the general population, attitudes of fear, dangerousness, responsibility for the condition, and avoidance seem to have been less frequent in our study. ${ }^{33-38}$ Notwithstanding, other studies conducted with relatives of people with severe mental illness have also confirmed a low level of perceived dangerousness, similarly to our study. ${ }^{39}$

The attitudes of our family members seem to be oriented towards providing support and assistance to the mentally ill, although they do consider compliance to pharmacological treatment and regular medical visits as essential for the patient's well-being, even if against the patient's own will. On the one hand, these data confirm a growing trend toward a continuous and strong support and involvement on the part of relatives of people with mental disorders. ${ }^{22,40,41}$ On the other hand, they reflect difficulties associated with empowerment and self-determination in people with schizophrenia, here manifested as a lack of recognition of the patient's participation and active involvement in the recovery process, even when pharmacologically treated, with 
occasional consequences in terms of non-adherence to treatment and rehabilitation outcomes. ${ }^{42-45}$

Some of the dimensions most closely related with stigma in the AQ-27, e.g., fear, dangerousness, avoidance, and responsibility, referred to by Corrigan et al. $^{10}$ as stereotypes, have historically contributed to create some of the most significant myths associated with mental disease and the mentally ill. ${ }^{46}$ The low scores obtained for these stereotypes in our study may be explained by the regular contact our relatives had with the condition and patient. Indeed, Corrigan et al. ${ }^{47,48}$ have alerted to the relevance and effectiveness of contact strategies when treating stigma and building representations of the condition and of the person carrying it (more adequate and more adjusted representations, based on contemporary knowledge). Recent findings have suggested that the acceptance and social integration and participation of people with mental illness in their community have been significantly and positively related with the previous experience with the illness in these communities. It therefore seems that familiarity (direct contact) with mental illness decreases the levels of stigma, social avoidance, and perceived dangerousness/unpredictability, possibly opening new opportunities and creating favorable conditions for social inclusion, conditions that improve social functioning and quality of life in this population. ${ }^{49}$

In early psychiatric practice, relatives of patients with mental illness refused to accompany the patient or participate in his/her treatment, explicitly refusing to play any role in caregiving and avoiding to get emotionally involved with the patient. Now, only some years after deinstitutionalization, the number of people with mental illness living with their families substantially increased. ${ }^{50,51}$ The absence of a sufficient number of community support facilities to sustain this paradigm shift in mental health care policies (now markedly community-oriented), has "pushed" these families, often ill equipped and poorly supported, into the main integrative resource providing support to patients who have been deinstitutionalized from specialist hospitals. ${ }^{52}$ Monitoring the quality of contact between families and their patients and the quality of the multidimensional support offered to these families seems to be an important strategy recognize the importance of mental health services, as pointed out in the systematic review conducted by the Cochrane Schizophrenia Group on family interventions in schizophrenia. ${ }^{53}$

Our data also seem to establish an inverse relationship between illness duration and coercion scores, pointing to a higher prevalence of this attitude in family members of people who got ill more recently. Even though the present study did not assess family relationships and structure, or family knowledge before the first crisis, our results can possibly be explained by the fact that, in the early phases of mental illness, families still do not have the necessary tools and knowledge to effectively manage this new reality, which ultimately imposes emotional and functional reorganization on the part of the family, in the sense of finding a new balance point in family dynamics. In addition, it is important to keep in mind that the illness is a new process for the patients themselves, who often show difficulties accepting the diagnosis or treatment and present periods of decompensation; in this scenario, the challenges and demands imposed on the family become exponentially more difficult. Illness course and (a usually long) evolution also increase the burden on the caregiver, a phenomenon extensively studied since the 1950s, referring to an increase in fatigue and a decrease in the energy necessary for coercion. ${ }^{22}$

In the analysis of coercive attitudes of family members towards the mentally ill, even though we have not assessed the quality of relationships among family members, it is important to emphasize that the prevalence of coercion was lower among spouses than among other, more distant, relatives, such as grandparents, uncles and aunts, nephews and nieces. This finding seems to reflect that close affective relationships work better as social and emotional support mechanisms, underscoring the importance of direct contact with the illness. Notwithstanding, we cannot refrain from mentioning the adverse consequence of this finding to the nuclear family, namely, the burden related with constantly supervising and stimulating the patient to take the medication, dealing with behavior problems, motivating the patient to practice self-care, preparing meals and supervising daily life activities because of the patient's difficulties performing them alone. ${ }^{54-57}$

A recent review conducted by Dias ${ }^{58}$ describes three studies involving caregivers of patients with mental disorders. First, the study by Gonçalves-Pereira, ${ }^{59}$ performed in Portugal with 80 caregivers of relatives with schizophrenia observed that caregivers with a strong involvement and spending a long time everyday with the patient presented relatively high scores for objective and subjective burden. Second, Östman \& Hansson ${ }^{60}$ investigated 162 relatives of psychiatric patients in Sweden and found higher burden scores in participants who lived with the patient. Third, a cross-cultural study by Magliano et al. ${ }^{61}$ assessed 236 family members who took care of people with schizophrenia and observed that the caregivers of younger patients more frequently adopted problem-solving coping strategies, including coercive attitudes towards treatment adherence. The burden of the caregiver was referred to by Dias as an important area for intervention and attention. 
With regard to the relationship between family members' education level and the presence of stigmatizing attitudes, interesting results were observed in the pity dimension, more present in relatives with low education levels (up to 4th grade) and less present in members who studied until the 12th year or beyond. These data point toward the importance of formal education in determining the way how the phenomenon is perceived and how people act about it. They also underscore the need for guiding and adjusting antistigma strategies to the different profiles of family members involved. ${ }^{5,62,63}$ In addition to formal education, mental health literacy is also determinant for a better management of the disease, and it also helps deal with the mentally ill and associated stigmas. ${ }^{48,64}$ According to Hinshaw, ${ }^{17}$ lack of family knowledge is a major obstacle to the adequate management of mental illness. Family-oriented psychoeducational interventions play a major role in changing this picture. 22,65 However, such interventions should be planned and conducted with care, as an increased consciousness about the disease may also increase the family's self-stigma. ${ }^{66}$ Regarding social stigma, although most studies suggest that the greater the knowledge about mental illness, the lower the tendency to agree with stigma and discrimination, ${ }^{64,65,67}$ some authors have observed associations between such knowledge and an unaltered or even increased social distance in relation to people with schizophrenia. ${ }^{68}$

Finally, if we analyze the correlations observed between the several dimensions of the AQ-27, we can see that our sample yielded several significant associations, including the one between a lower degree of causal attribution to the patient on the one hand (e.g., responsibility and controllability of the illness and symptoms) and lower scores of dangerousness, fear, and avoidance and higher help and pity scores on the other. According to the attribution model proposed by Corrigan et al., ${ }^{10}$ three cognitive-emotional processes determine human behavior: attribution process, perceived dangerousness, and familiarity. In the first process, the individual tends to make attributions to the cause and controllability of a given behavior shown by someone else, associating these aspects with responsibility. In the present study, the cause of disease was probably not associated with internal factors, but rather with factors external to the individual, and therefore responsibility attributions were low. ${ }^{69}$ Consequently, a lower frequency of negative emotional responses was observed, combined with an increased frequency of helping beh aviors. With regard to the second process, perceived dangerousness is determinant in eliciting negative attitudes and behavioral responses, a phenomenon that was not observed in our sample, except for coercion, which showed high scores. Finally, the third process (familiarity) was observed in our study. According to Angermeyer et al. ${ }^{49}$ and Penn \& Couture, ${ }^{70}$ the greater the level of familiarity, the lower the level of stigma, social avoidance, and perceived dangerousness. As a result, familiarity with severe mental illness among the participants of the present study, resulting from their role in their families and in the caregiving process, is a protective factor against stigma, which indeed was associated with lower scores in most dimensions.

Some limitations of the present study deserve to be mentioned. First and foremost, our sample size was small. Second, we did not assess family member characteristics, e.g., quality of family relationships, mental health literacy, and daily behaviors of the family members (only attitudes were investigated).

\section{Conclusion}

The present study used the AQ-27 to assess stigma associated with schizophrenia in a group of relatives of patients with the disorder and revealed that, overall, participants had positive and little stigmatizing attitudes towards people with schizophrenia, probably as a result of their familiarity with severe mental illness, of an adequate attribution process, and of the low levels of perceived dangerousness. Notwithstanding, the high scores observed for coercion may suggest concealed stigmas with potentially negative influences on the self-determination of the person with the mental illness. Monitoring the quality of relationships between the mentally ill and their family members, as well as developing and implementing family-oriented psychoeducational interventions, are suggested strategies for the prevention of stigmatizing attitudes in the family. 


\section{References}

1. Corrigan P, Watson A, Barr L. The self-stigma of mental illness: implications for self-esteem and self-efficacy. J Soc Clin Psychol. 2006;25:875-84.

2. Watson AC, Corrigan P, Larson JE, Sells M. Self-stigma in people with mental illness. Schizophr Bull. 2007;33:1312-8.

3. Link BG, Phelan JC. Stigma and its public health implications. Lancet. 2006;367:528-9.

4. Angermeyer MC, Holzinger A, Matschinger H. Emotional reactions to people with mental illness. Epidemiol Psichiatr Soc. 2010;19:26-32.

5. Sartorius N, Gaebel W, Cleveland H-R, Stuart H, Akiyama T, Arboleda-Flórez J, et al. WPA guidance on how to combat stigmatization of psychiatry and psychiatrists. World Psychiatry. 2010;9:131-44.

6. Thornicroft G, Alem A, Santos RAD, Barley E, Drake RE, Gregorio G, et al. WPA guidance on steps, obstacles and mistakes to avoid in the implementation of community mental health care. World Psychiatry. 2010;9:67-77.

7. Corrigan P, Watson AC. The paradox of self-stigma and mental illness. Clin Psychol Sci Pract. 2002;9:35-53.

8. Corrigan P. The impact of stigma on severe mental illness. Cognit Behav Pract. 1998;5:201-22.

9. Corrigan P. Mental health stigma as social attribution: implications for research methods and attitude change. Clin Psychol Sci Pract. 2000;7:48-67.

10. Corrigan P, Markowitz F, Watson A, Rowan D, Kubiak MA. An attribution model of public discrimination towards persons with mental illness. J Health Soc Behav. 2003;44:162-79.

11. Weiner B. A cognitive (attribution)-emotion-action model of helping behavior: an analysis of judgments of help giving. J Pers Soc Psychol. 1980;39:186-200.

12. Heider F. The psychology of interpersonal relations. New York: Wiley; 1958.

13.World Health Organization. Mental health: facing the challenges, building solutions: report from the WHO European Ministerial Conference. Helsinki: WHO; 2005.

14. Organização Mundial da Saúde. Pacto europeu para a saúde mental e bem-estar - versão portuguesa. Bruxelas: OMS; 2008.

15. Leff J, Warner R. Social inclusion of people with mental illness. Cambridge: Cambridge University Press; 2006.

16. Thornicroft G, Rose D, Kassam A, Sartorius N. Stigma: ignorance, prejudice or discrimination. $\mathrm{Br}$ J Psychiatry. 2007;190:192-3.

17. Hinshaw SP. The mark of shame - stigma of mental illness and an agenda for change. New York: Oxford University Press; 2007.

18. Corrigan $\mathrm{P}$, Kleinlein $\mathrm{P}$. The impact of mental illness stigma. In: Corrigan $\mathrm{P}$, editor. On the stigma of mental illness - practical strategies for research and social change. Washington: American Psychological Association; 2005. p. 11-44.

19. Goffman E. Stigma - notes on the management of spoiled identity. New York: Simon \& Schuster; 1963.

20. Struening EL, Perlick DA, Link BG, Hellman F, Herman D, Sirey JA. Stigma as a barrier to recovery: the extent to which caregivers believe most people devalue consumers and their families. Psychiatr Serv. 2001;52:1633-8.

21. Wong C, Davidson L, Anglin D, Link B, Gerson R, Malaspina $D$, et al. Stigma in families of individuals in early stages of psychotic illness: family stigma and early psychosis. Early Interv Psychiatry. 2009;3:108-15.
22. McFarlane WR. Multifamily groups in the treatment of severe psychiatric disorders. New York: Guilford; 2002.

23. Marques A. Intervenção em grupo com familiares de doentes com esquizofrenia. In: Guerra M, Lima L, editors. Intervenção psicológica em grupos em contextos de saúde. Lisboa: Climepsi; 2005. p. 229-56.

24. Larson JE, Corrigan P. The stigma of families with mental illness. Acad Psychiatry. 2008;32:87-91.

25. Almeida MM, Schal VT, Martins AM, Modena CM. A sobrecarga de cuidadores de pacientes com esquizofrenia. Rev Psiquiatr Rio Gd Sul. 2010;32:73-9.

26. Queirós C, Sousa S, Marques A. A B-Learning course to reduced self-stigma in schizophrenia: preparing individuals to active life. Eur Psychiatry. 2011;26(Supplement 1):1485.

27. Cabral RR, Chaves AC. Conhecimento sobre a doença e expectativas do tratamento em familiares de pacientes no primeiro episódio psicótico: um estudo transversal. Rev Psiquiatr Rio Gd Sul. 2005;27:32-8.

28. Veltman A, Cameron JI, Stewart DE. The experience of providing care to relatives with chronic mental illness. J Nerv Ment Dis. 2002;190:108-14.

29. Corrigan P. Attribution questionnaire (AQ-27). http://www. stigmaandempowerment.org/resources. Accessed 2011 Oct.

30. Sousa S, Queirós C, Marques A, Rocha N, Fernandes A. Versão preliminar portuguesa do Attribution Questionnaire (AQ-27), adaptada com autorização de P. Corrigan. Porto: FPCEUP/ESTSPIPP; 2008.

31. Marques A, Barbosa T, Queirós C. Stigma in mental health: perceptions of students who will be future health professionals. Eur Psychiatry. 2011;26(Supplement 1):1439.

32. Barrantes FJ. O estigma na esquizofrenia: atitude dos profissionais da saúde mental [thesis]. Porto: Universidade Católica Portuguesa; 2010.

33. Angermeyer MC, Dietrich S. Public beliefs about and attitudes towards people with mental illness: a review of population studies. Acta Psychiatr Scand. 2006;113:163-79.

34. Corrigan P, Larson J, Sells M, Niessen N, Watson AC. Will filmed presentations of education and contact diminish mental illness stigma? Community Ment Health J. 2007;43:171-81.

35. Feldman DB, Crandall CS. Dimensions of mental illness stigma: what about mental illness causes social rejection? ] Soc Clin Psychol. 2007;26:137-54.

36. Marie D, Miles B. Social distance and perceived dangerousness across four diagnostic categories of mental disorder. Aust N Z J Psychiatry. 2008;42:126-33.

37. Martin JK, Pescosolido BA, Tuch SA. Of fear and loathing: the role of disturbing behavior, labels, and causal attributions in shaping public attitudes toward people with mental illness. J Health Soc Behav. 2000;41:208-23.

38. Rüsch N, Todd AR, Bodenhausen GV, Corrigan PW. Biogenetic models of psychopathology, implicit guilt, and mental illness stigma. Psychiatry Res. 2010;179:328-32.

39. Thompson AH, Stuart H, Bland RC, Arboleda-Florez J, Warner R, Dickson RA. Attitudes about schizophrenia from the pilot site of the WPA worldwide campaign against the stigma of schizophrenia. Soc Psychiatry Psychiatr Epidemiol. 2002;37:475-82

40. Larson JE, Corrigan P. The stigma of families with mental illness. Acad Psychiatry. 2008;32:87-91.

41. Arboleda-Flórez J. The rights of a powerless legion. In: Arboleda-Flórez J, Sartorius N, editors. Understanding the stigma of mental illness - theory and interventions. West Sussex: Wiley; 2008. p. 1-17. 
42. Deegan P. The importance of personal medicine: a qualitative study of resilience in people with psychiatric disabilities. Scand J Public Health. 2005;66(Suppl.):29-35.

43. Marques AJ, Queirós C, Rocha N. Auto-determinação e reabilitação psicossocial de pessoas com esquizofrenia. Saude Ment. 2006;8(3):11-19.

44. Medalia A, Brekke J. In search of a theoretical structure for understanding motivation in schizophrenia. Schizophr Bull. 2010;36:912-8.

45. Sibitz I, Unger A, Woppmann A, Zidek T, Amering M. Stigma resistance in patients with schizophrenia. Schizophr Bull. 2011;37:316-323.

46. Thornicroft G. Shunned: discrimination against people with mental illness. J Occup Psychol Employ Disabil. 2009;11:56-8.

47. Corrigan P, Rowan D, Green A, Lundin R, River P, UphoffWasowski $K$, et al. Challenging two mental illness stigmas: personal responsibility and dangerousness. Schizophr Bull. 2002;28:293-309.

48. Corrigan $P$, Mueser KT, Bond GR, Drake RE, Solomon P. Principles and practice of psychiatric rehabilitation: an empirical approach. New York: Guilford; 2008.

49. Angermeyer MC, Matschinger H, Corrigan PW. Familiarity with mental illness and social distance from people with schizophrenia and major depression: testing a model using data from a representative population survey. Schizophr Res. 2004;69:175-82.

50. Hasson-Ohayon I, Levy I, Kravetz S, Vollanski-Narkis A, Roe D. Insight into mental illness, self-stigma, and the family burden of parents of persons with a severe mental illness. Compr Psychiatry. 2011;52:75-80.

51. Spadini LS, Souza MC. A doença mental sob o olhar de pacientes e familiares. Rev Esc Enfermagem USP. 2006;40:123-7.

52. Marques A. Modelo Integrado de desenvolvimento pessoal: um modelo de reabilitação psicossocial para pessoas com incapacidades psiquiátricas [dissertation]. Porto: Universidade do Porto; 2007.

53. Pharoah F, Mari J, Rathbone J, Wong W. Family intervention for schizophrenia [review]. Cochrane Database Syst Rev. 2010;11:155.

54. Bandeira M, Calzavara MG, Varella AA. Escala de sobrecarga dos familiares de pacientes psiquiátricos: adaptação transcultural para o Brasil (FBIS-BR). J Bras Psiquiatr. 2005;54:206-14.

55. Barroso SM, Bandeira M, Nascimento E. Sobrecarga de familiares de pacientes psiquiátricos atendidos na rede pública. Rev Psiquiatr Clin. 2007;34:270-7.

56. Campos L, Teixeira JM, Cardoso CM. Do burden familiar... à experiência do cuidar: qual o modelo teórico mais adequado para a prestação de cuidados informais ao doente esquizofrénico? Saude Ment. 2005;7(3):21-6.

57. Xavier M, Gonçalves-Pereira M, Corrêa BB, Caldas de Almeida JM. Questionário de problemas familiares: desenvolvimento da versão portuguesa de um instrumento de avaliação de sobrecarga familiar Psicol Saude Doenças. 2002;3:165-77.
58. Dias EA. Sobrecarga vivenciada por familiares cuidadores de pacientes esquizofrénicos e sua relação com a depressão [thesis]. Lisboa: Universidade Nova de Lisboa; 2011.

59. Gonçalves Pereira M. Repercussões da doença mental na família: um estudo de familiares de doentes psicóticos [thesis]. Lisboa: Universidade Nova de Lisboa; 1996.

60.Östman M, Hansson L. Appraisal of caregiving, burden and psychological distress in relatives of psychiatric inpatients. Eur Psychiatry. 2004;19:402-7.

61. Magliano L, Fadden G, Madianos M, Caldas de Almeida JM, Held T, Guarneri M, et al. Burden on the families of patients with schizophrenia: results of the BIOMED I study. Soc Psychiatry Epidemiol. 1998;33:405-12.

62. Corrigan P, Penn D. Lessons from social psychology on discrediting psychiatric stigma. Am Psychol. 1999;54:765-76.

63. Pinfold $V$, Toulmin $H$, Thornicroft $G$, Huxley $P$, Farmer $P$, Graham T. Reducing psychiatric stigma and discrimination: evaluation of educational interventions in UK secondary schools. Br J Psychiatry. 2003;182:342-6.

64. Altindag A, Yanik M, Ucok A, Alptekin K, Ozkan M. Effects of an antistigma program on medical students' attitudes towards people with schizophrenia. Psychiatry Clin Neurosci. 2006;60:283-8.

65. Corrigan P, Thompson V, Lambert D, Sangster $Y$, Noel J, Campbell J. Perceptions of discrimination among persons with serious mental illness. Psychiatr Serv. 2003;54:1105-10.

66. Hasson-Ohayon I, Levy I, Kravetz S, Vollanski-Narkis A, Roe D. Insight into mental illness, self-stigma, and the family burden of parents of persons with a severe mental illness. Compr Psychiatry. 2011;52:75-80.

67. Link BG, Cullen FT. Contact with the mentally ill and perceptions of how dangerous they are. J Health Soc Behav. 1986;27:289-302.

68. Angermeyer $M$, Holzinger $A$, Matschinger $H$. Mental health literacy and attitude towards people with mental illness: a trend analysis based on population surveys in the eastern part of Germany. Eur Psychiatry. 2009;24:225-32.

69. Corrigan PW, Watson AC, Warpinski AC, Gracia G. Stigmatizing attitudes about mental illness and allocation of resources to mental health services. Community Ment Health J. 2004; $40: 297-307$.

70. Penn D, Couture S. Strategies for reducing stigma towards persons with mental illness. World Psychiatry. 2002;1:20-1.

\author{
Correspondence \\ Cristina Queirós \\ Faculdade de Psicologia e de Ciências da Educação, \\ Universidade do Porto \\ Rua Alfredo Allen, $\mathrm{s} / \mathrm{n}^{\circ}$ \\ 4200-135 - Porto - Portugal \\ Tel. : +351-226079720 \\ E-mail: cqueiros@fpce.up.pt
}


Appendix 1 - Non-significant results obtained in the comparative analyses

\begin{tabular}{|c|c|c|c|c|c|c|}
\hline Dimension & Type of relationship & $\mathbf{n}$ & Mean & $\begin{array}{l}\text { Standard } \\
\text { deviation }\end{array}$ & $\begin{array}{c}\text { ANOVA } \\
\text { (F) }\end{array}$ & $\mathbf{p}$ \\
\hline \multirow[t]{5}{*}{ Responsibility } & Parents & & & & & \\
\hline & Spouse & 6 & 3.2778 & 1.34026 & & \\
\hline & Sibling (in-law) & 13 & 3.1795 & .96815 & 0.768 & 0.519 \\
\hline & Other & 4 & 2.5000 & .43033 & & \\
\hline & Total & 40 & 2.9333 & 1.12774 & & \\
\hline \multirow[t]{5}{*}{ Pity } & Parents & 17 & 7.3725 & 1.58062 & & \\
\hline & Spouse & 6 & 6.7222 & 1.66556 & & \\
\hline & Sibling (in-law) & 13 & 6.1795 & 2.00285 & 1.284 & 0.295 \\
\hline & Other & 4 & 7.4167 & 1.66389 & & \\
\hline & Total & 40 & 6.8917 & 1.76930 & & \\
\hline \multirow[t]{5}{*}{ Anger } & Parents & 17 & 3.6667 & 2.11476 & & \\
\hline & Spouse & 6 & 3.6667 & 2.35702 & & \\
\hline & Sibling (in-law) & 13 & 2.7949 & 1.38469 & 1.244 & 0.308 \\
\hline & Other & 4 & 2.0000 & .81650 & & \\
\hline & Total & 40 & 3.2167 & 1.87585 & & \\
\hline \multirow[t]{5}{*}{ Dangerousness } & Parents & 17 & 3.0392 & 1.77123 & & \\
\hline & Spouse & 6 & 3.8889 & 2.64715 & & \\
\hline & Sibling (in-law) & 13 & 3.2308 & 1.99251 & 0.935 & 0.434 \\
\hline & Other & 4 & 1.8333 & .57735 & & \\
\hline & Total & 40 & 3.1083 & 1.92359 & & \\
\hline \multirow[t]{5}{*}{ Fear } & Parents & 17 & 2.7843 & 2.22030 & & \\
\hline & Spouse & 6 & 3.5556 & 3.03071 & & \\
\hline & Sibling (in-law) & 13 & 2.6154 & 2.16387 & 0.996 & 0.406 \\
\hline & Other & 4 & 1.0833 & .16667 & & \\
\hline & Total & 40 & 2.6750 & 2.24241 & & \\
\hline \multirow[t]{5}{*}{ Help } & Parents & 17 & 7.7451 & .77754 & & \\
\hline & Spouse & 6 & 6.4444 & 2.84930 & & \\
\hline & Sibling (in-law) & 13 & 7.2821 & 1.65466 & 1.172 & 0.334 \\
\hline & Other & 4 & 6.9167 & .87665 & & \\
\hline & Total & 40 & 7.3167 & 1.55057 & & \\
\hline \multirow[t]{5}{*}{ Segregation } & Parents & 17 & 5.0000 & 2.05142 & & \\
\hline & Spouse & 6 & 3.5000 & 2.77088 & & \\
\hline & Sibling (in-law) & 13 & 3.3333 & 1.95789 & 2.191 & 0.106 \\
\hline & Other & 4 & 3.0000 & .98131 & & \\
\hline & Total & 40 & 4.0333 & 2.16525 & & \\
\hline \multirow[t]{5}{*}{ Avoidance } & Parents & 17 & 3.0588 & 2.06235 & & \\
\hline & Spouse & 6 & 3.1111 & 2.95647 & & \\
\hline & Sibling (in-law) & 13 & 3.4615 & 2.35914 & 0.080 & 0.971 \\
\hline & Other & 4 & 3.1667 & 2.15166 & & \\
\hline & Total & 40 & 3.2083 & 2.22865 & & \\
\hline Dimension & Education level & $\mathbf{n}$ & Mean & $\begin{array}{l}\text { Standard } \\
\text { deviation }\end{array}$ & $\begin{array}{l}\text { ANOVA } \\
\text { (F) }\end{array}$ & $\mathbf{p}$ \\
\hline \multirow[t]{4}{*}{ Responsibility } & Up to 4th grade & 17 & 2.5294 & 1.16702 & & \\
\hline & Up to 9 th grade & 11 & 3.2727 & .94066 & 2.009 & 0.148 \\
\hline & 12 th grade or beyond & 12 & 3.1944 & 1.13225 & & \\
\hline & Total & 40 & 2.9333 & 1.12774 & & \\
\hline \multirow[t]{4}{*}{ Anger } & Up to 4 th grade & 17 & 3.6275 & 2.32404 & & \\
\hline & Up to 9 th grade & 11 & 3.0909 & 1.57121 & 0.795 & 0.459 \\
\hline & 12 th grade or beyond & 12 & 2.7500 & 1.36423 & & \\
\hline & Total & 40 & 3.2167 & 1.87585 & & \\
\hline \multirow[t]{4}{*}{ Dangerousness } & Up to 4 th grade & 17 & 2.9608 & 2.26042 & & \\
\hline & Up to 9 th grade & 11 & 2.8182 & 1.06837 & 0.528 & 0.594 \\
\hline & 12 th grade or beyond & 12 & 3.5833 & 2.07011 & & \\
\hline & Total & 40 & 3.1083 & 1.92359 & & \\
\hline \multirow[t]{4}{*}{ Fear } & Up to 4th grade & 17 & 2.8824 & 2.70786 & & \\
\hline & Up to 9 th grade & 11 & 2.0303 & 1.27762 & 0.620 & 0.543 \\
\hline & 12 th grade or beyond & 12 & 2.9722 & 2.25836 & & \\
\hline & Total & 40 & 2.6750 & 2.24241 & & \\
\hline
\end{tabular}


Appendix 1 - Non-significant results obtained in the comparative analyses (cont.)

\begin{tabular}{|c|c|c|c|c|c|c|}
\hline Dimension & Education level & $\mathbf{n}$ & Mean & $\begin{array}{l}\text { Standard } \\
\text { deviation }\end{array}$ & $\begin{array}{c}\text { ANOVA } \\
\text { (F) }\end{array}$ & $\mathbf{p}$ \\
\hline \multirow[t]{4}{*}{ Help } & Up to 4th grade & 17 & 7.3137 & 1.80074 & & \\
\hline & Up to 9 th grade & 11 & 7.9394 & .62925 & 1.754 & 0.187 \\
\hline & 12 th grade or beyond & 12 & 6.7500 & 1.64609 & & \\
\hline & Total & 40 & 7.3167 & 1.55057 & & \\
\hline \multirow[t]{4}{*}{ Coercion } & Up to 4 th grade & 17 & 6.6078 & 1.56452 & & \\
\hline & Up to 9 th grade & 11 & 6.8182 & .67270 & 1.053 & 0.359 \\
\hline & 12 th grade or beyond & 12 & 7.2778 & 1.06205 & & \\
\hline & Total & 40 & 6.8667 & 1.23298 & & \\
\hline \multirow[t]{4}{*}{ Segregation } & Up to 4th grade & 17 & 4.7843 & 2.47751 & & \\
\hline & Up to 9th grade & 11 & 3.6970 & 1.49410 & 1.981 & 0.152 \\
\hline & 12 th grade or beyond & 12 & 3.2778 & 2.01426 & & \\
\hline & Total & 40 & 4.0333 & 2.16525 & & \\
\hline \multirow[t]{4}{*}{ Avoidance } & Up to 4 th grade & 17 & 3.0392 & 2.42350 & & \\
\hline & Up to 9 th grade & 11 & 2.4545 & 1.03573 & 1.794 & 0.180 \\
\hline & 12 th grade or beyond & 12 & 4.1389 & 2.55627 & & \\
\hline & Total & 40 & 3.2083 & 2.22865 & & \\
\hline Dimension & Illness duration & $\mathbf{n}$ & Mean & $\begin{array}{l}\text { Standard } \\
\text { deviation }\end{array}$ & $\begin{array}{c}\text { ANOVA } \\
(\mathrm{F})\end{array}$ & $\mathbf{p}$ \\
\hline \multirow[t]{5}{*}{ Responsibility } & 3-9 years & 6 & 3.4444 & .98131 & & \\
\hline & $15-21$ years & 11 & 2.8485 & 1.29412 & & \\
\hline & $24-37$ years & 10 & 2.9000 & 1.40590 & 0.480 & 0.698 \\
\hline & Does not know & 13 & 2.7949 & .83376 & & \\
\hline & Total & 40 & 2.9333 & 1.12774 & & \\
\hline \multirow[t]{5}{*}{ Pity } & 3-9 years & 6 & 7.0000 & 2.75681 & & \\
\hline & $15-21$ years & 11 & 6.3636 & 1.69610 & & \\
\hline & $24-37$ years & 10 & 6.9000 & 1.83955 & 0.525 & 0.668 \\
\hline & Does not know & 13 & 7.2821 & 1.28269 & & \\
\hline & Total & 40 & 6.8917 & 1.76930 & & \\
\hline \multirow[t]{5}{*}{ Anger } & 3-9 years & 6 & 3.3889 & 1.61130 & & \\
\hline & $15-21$ years & 11 & 3.4545 & 2.19227 & & \\
\hline & $24-37$ years & 10 & 2.9000 & 2.19455 & 0.161 & 0.922 \\
\hline & Does not know & 13 & 3.1795 & 1.60794 & & \\
\hline & Total & 40 & 3.2167 & 1.87585 & & \\
\hline \multirow[t]{5}{*}{ Dangerousness } & 3-9 years & 6 & 3.1667 & 1.44145 & & \\
\hline & $15-21$ years & 11 & 3.2727 & 1.71800 & & \\
\hline & $24-37$ years & 10 & 3.2000 & 2.30512 & 0.095 & 0.963 \\
\hline & Does not know & 13 & 2.8718 & 2.14967 & & \\
\hline & Total & 40 & 3.1083 & 1.92359 & & \\
\hline \multirow[t]{5}{*}{ Fear } & 3-9 years & 6 & 3.8333 & 2.91928 & & \\
\hline & $15-21$ years & 11 & 2.4848 & 1.49342 & & \\
\hline & $24-37$ years & 10 & 2.6667 & 2.51416 & 0.659 & 0.583 \\
\hline & Does not know & 13 & 2.3077 & 2.31125 & & \\
\hline & Total & 40 & 2.6750 & 2.24241 & & \\
\hline \multirow[t]{5}{*}{ Help } & 3-9 years & 6 & 7.3889 & 1.80637 & & \\
\hline & $15-21$ years & 11 & 7.6970 & .70639 & & \\
\hline & $24-37$ years & 10 & 7.5333 & 2.32113 & 0.767 & 0.520 \\
\hline & Does not know & 13 & 6.7949 & 1.23632 & & \\
\hline & Total & 40 & 7.3167 & 1.55057 & & \\
\hline \multirow[t]{5}{*}{ Segregation } & 3-9 years & 6 & 4.1667 & 2.65623 & & \\
\hline & $15-21$ years & 11 & 3.9091 & 2.03901 & & \\
\hline & $24-37$ years & 10 & 3.6667 & 2.07275 & 0.200 & 0.896 \\
\hline & Does not know & 13 & 4.3590 & 2.31525 & & \\
\hline & Total & 40 & 4.0333 & 2.16525 & & \\
\hline \multirow[t]{5}{*}{ Avoidance } & 3-9 years & 6 & 4.8889 & 2.50037 & 1.606 & 0.205 \\
\hline & $15-21$ years & 11 & 2.7273 & 1.35661 & & \\
\hline & $24-37$ years & 10 & 2.6333 & 2.71006 & & \\
\hline & Does not know & 13 & 3.2821 & 2.14237 & & \\
\hline & Total & 40 & 3.2083 & 2.22865 & & \\
\hline
\end{tabular}

